\title{
Effect of Schiff base Cu(II) complexes on signaling pathways in HT-29 cells
}

\author{
KATARÍNA KOŇARIKOVÁ ${ }^{1}$, GEORGIOS A. PERDIKARIS ${ }^{1}$, HELENA GBELCOVÁ ${ }^{2}$, LUCIA ANDREZÁLOVÁ ${ }^{1}$, \\ MARTIN ŠVÉDA ${ }^{3}$, TOMÁŠ RUML ${ }^{3}$, LUCIA LAUBERTOVÁ ${ }^{1}$ and INGRID ŽITŇANOVÁ ${ }^{1}$ \\ ${ }^{1}$ Institute of Medical Chemistry, Biochemistry and Clinical Biochemistry; \\ ${ }^{2}$ Institute of Medical Biology, Genetics and Clinical Genetics, Faculty of Medicine, Comenius University, 81372 Bratislava, \\ Slovak Republic; ${ }^{3}$ Department of Biochemistry and Microbiology, Institute of Chemical Technology, \\ Faculty of Food Biochemical Technology, 16628 Prague, Czech Republic
}

Received February 24, 2016; Accepted July 12, 2016

DOI: $10.3892 / \mathrm{mmr} .2016 .5739$

\begin{abstract}
Schiff base copper (II) complexes are known for their anticancer, antifungal, antiviral and anti-inflammatory activities. The aim of the current study was to investigate biological effects of Schiff base $\mathrm{Cu}$ (II) complexes $(0.001-100 \mu \mathrm{mol} / \mathrm{l})-\left[\mathrm{Cu}_{2}(\mathrm{sal}-\mathrm{D}, \mathrm{L}-\mathrm{glu})_{2}\right.$ (isoquin oline) $\left.{ }_{2}\right] \cdot 2 \mathrm{C}_{2} \mathrm{H}_{5} \mathrm{OH}$ (1), [Cu(sal-5-met-L-glu) $\left.\left(\mathrm{H}_{2} \mathrm{O}\right)\right] \cdot \mathrm{H}_{2} \mathrm{O}$ (2), $\left.\left[\mathrm{Cu}(\text { ethanol })_{2} \text { (imidazole }\right)_{4}\right]\left[\mathrm{Cu}_{2} \text { (sal-D, L-glu }\right)_{2}$ (imidazole $\left.)_{2}\right]$ (3), [Cu(sal-D,L-glu)(2-methylimidazole)] (4) on the human colon carcinoma cells HT-29, the mouse noncancerous cell line NIH-3T3 and the human noncancerous fibroblast cell line VH10. The results suggested that $\mathrm{Cu}$ (II) complexes exhibit cytotoxic effects against the HT-29 cell line, while complexes 3 and 4 were the most effective. Subsequent to $72 \mathrm{~h}$ of incubation, apoptosis was observed in the HT-29 cells induced by $\mathrm{Cu}$ (II) complexes $1(0.1,1,10$ and $50 \mu \mathrm{mol} / \mathrm{l})$, $2(1,10,50$ and $100 \mu \mathrm{mol} / \mathrm{l}), 3(0.01,1,10$ and $50 \mu \mathrm{mol} / \mathrm{l})$ and $4(0.01,0.1,1$ and $10 \mu \mathrm{mol} / \mathrm{l})$. The apoptotic pathways activated by the $\mathrm{Cu}$ (II) complexes were identified. The results indicated that complexes 2, 3 and 4 were able to induce the mitochondria-dependent pathway of apoptosis in HT-29 cells, while complex 1 was obsered to activate the extrinsic pathway of apoptosis. The levels of the anti-apoptotic protein Bcl-2 were reduced and those of the pro-apoptotic protein Bax increased following treatment with complexes 2,3 and 4. Complex 1 had no effect on Bax protein expression. Complexes 2 and 3 induced elevation of cytochrome $c$ (cyt c), while complex 4 induced a time-dependent elevation of cyt $\mathrm{c}$ levels. No cyt $\mathrm{c}$ was detected in HT-29 cells exposed to complex 1, suggesting that $\mathrm{Cu}$ (II)
\end{abstract}

Correspondence to: Dr Ingrid Žitňanová, Institute of Medical Chemistry, Biochemistry and Clinical Biochemistry, Faculty of Medicine, Comenius University, Sasinkova 2, 81372 Bratislava, Slovak Republic

E-mail: ingrid.zitnanova@fmed.uniba.sk

Key words: copper complexes, Schiff base, colon cancer, HT-29 cell line, apoptosis complexes activated the extrinsic pathway of apoptosis. The results from the current study in addition to previous studies suggest that Schiff base Cu (II) complexes have potential as novel anticancer drugs.

\section{Introduction}

Colorectal cancer (CRC) is the third most common type of cancer worldwide and is the fourth most common cause of cancer-associated mortality (1). To treat cancer, multiple interventions are required, including surgery, chemotherapy and radiotherapy, with the goal to cure the disease or prolong and improve quality of life (2). Chemotherapy has been demonstrated to be effective in cancer treatment, and has helped to save lives of millions of patients worldwide (3). There are numerous chemotherapeutic drugs that are commonly used, which can be effective in certain cancer types, however, chemotherapy does not specifically target cancer cells, therefore results in numerous side effects (4). The majority of drugs used for the treatment of cancer are cytotoxic drugs interfering with the operation of the cancer cells. Cytotoxic drugs can be harmful unless they are specific to cancer cells. Specificity is a challenge, due to the fact that the modifications required to convert a noncancerous cell into a cancerous cell are slight. To design novel selective drugs for cancer cells, with reduced side effects, is a key challenge (5). An important class of compounds with a variety of biological and clinical applications are Schiff bases (6). Copper is a metal long used for medicinal applications and its potential anticancer activity has been recently reported (7). Copper-based complexes have become a focus, due to the assumption that endogenous metals may be less toxic for normal cells compared with cancer cells. Differential response between normal and tumor cells to copper in addition to the altered metabolism of cancer cells are the basis for development of copper complexes with antineoplastic characteristics (8). Salicylaldehyde-derived copper (II) Schiff base complexes are promising anticancer agents as a result of their manifold properties such as anticancer and antifungal properties (9) antiviral, anti-inflammatory, antimicrobial and antioxidant activities (10). In addition, their transition metal complexes exhibit enhanced pharmacological properties (11). 
In the current study, four different copper (II) complexes containing Schiff bases derived from salicylaldehyde and glutamic acid were used, in addition to molecular $O$-or $\mathrm{N}$-donor ligands, in order to examine the anticancer activities.

\section{Materials and methods}

Cell cultures. Human colon cancercells (HT-29), non-cancerous human cells (VH10), human embryonal non-cancerous cells (HEK-293T), mouse cells (NIH-3T3) and mouse leukemia cells (L1210) were purchased from the American Type Culture Collection (Manassas, VA, USA). Cells were maintained in Dulbecco's modified Eagle's medium (DMEM; Life Technologies; Thermo Fisher Scientific, Inc., Waltham, MA, USA) containing $10 \%$ fetal bovine serum, $100 \mu \mathrm{g} / \mathrm{ml}$ streptomycin and $100 \mathrm{U} / \mathrm{ml}$ penicillin $\mathrm{G}$ at $37^{\circ} \mathrm{C}$ in a humidified atmosphere of $5 \% \mathrm{CO}_{2} / 95 \%$ air.

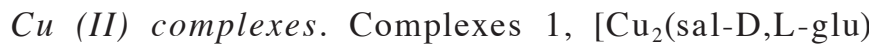
${ }_{2}$ (isoquinoline $\left.)_{2}\right] \cdot 2 \mathrm{C}_{2} \mathrm{H}_{5} \mathrm{OH} ; 2,[\mathrm{Cu}($ sal-5-met-L-glu) $\left.\left(\mathrm{H}_{2} \mathrm{O}\right)\right] \cdot \mathrm{H}_{2} \mathrm{O} ; 3,\left[\mathrm{Cu}(\text { ethanol })_{2}(\text { imidazole })_{4}\right]\left[\mathrm{Cu}_{2}(\right.$ sal-D, L-glu $\left.)_{2}(\text { imidazole })_{2}\right]$; and 4, [Cu(sal-D,L-glu)(2-methylimidazole)] were prepared, where (sal-D,L-glu) or (sal-L-glu) is $\mathrm{N}$-salicylidene-D, L- or L-glutamate and (sal-5-met-L-glu) is $\mathrm{N}$-salicylidene-5-methylester-L-glutamate. The synthesis and the structure of the complexes are described in Nakao et al (12), Krätsmár-Šmogrovič et al (13) and Langer et al (14-17).

Cytotoxicity analysis. The effects of $\mathrm{Cu}$ (II) complexes on viability of cancerous and noncancerous cells were determined by direct counting of viable cells by the trypan blue exclusion assay in addition to using the 3-(4,5-dimethylthiazol-2-yl) 2,5-diphenyltetrazolium bromide (MTT) colorimetric technique. Cells were placed $\left(8 \times 10^{3}\right.$ cells $/ 200 \mu 1$ well) in individual wells of 96-multiwell plates. Each concentration was tested four times and all dye exclusion tests were performed in triplicate. $\mathrm{Cu}$ (II) complexes were diluted with distilled water and final concentrations of the complexes added to the cells were 0.001 , $0.01,0.1,1,10,50$ and $100 \mu \mathrm{mol} / 1$. Following $72 \mathrm{~h}$ exposure to 7 concentrations of $\mathrm{Cu}$ (II) complexes $\left(37^{\circ} \mathrm{C}\right.$, humidified atmosphere of $5 \% \mathrm{CO}_{2} / 95 \%$ air), cells were treated with MTT solution [5 mg/ml in phosphate-buffered saline (PBS), $20 \mu \mathrm{l}]$ for $4 \mathrm{~h}$. The dark crystals of formazan formed in intact cells were dissolved in dimethyl sulfoxide $(200 \mu 1)$. The plates were shaken for $15 \mathrm{~min}$ and the optical density was determined at $595 \mathrm{~nm}$ using a MicroPlate Reader (Biotek Instruments, Inc., Winooski, VT, USA).

Staining ofactinfilaments. The cell suspension $\left(2 \times 10^{3}\right.$ cells/well $)$ was seeded into 6-well chamber slides. Cells were then treated with $\mathrm{Cu}$ (II) complexes ( $\mathrm{IC}_{50}$ concentration) for $24 \mathrm{~h}$. Non-treated cells were set as the controls. For staining of the actin filaments, the following procedures were conducted at room temperature. Cells were washed with PBS and were fixed with $4 \%$ formaldehyde in PBS for $20 \mathrm{~min}$, followed by washing with PBS. Cells were then stained with $40 \mu \mathrm{l} /$ slide phalloidine $(1 \mu \mathrm{g} / \mathrm{ml})$ for $30 \mathrm{~min}$ in dark. Subsequent to incubation, cells were washed with distilled water. Actin fibers were visualized by fluorescence microscopy (Zeiss, Oberkochen, Germany) and images were captured under a magnification of x600.
Detection of apoptosis. Untreated (control) and drug-treated (0.1-100 $\mu \mathrm{mol} / 1)$ cancerous HT-29 cells $\left(1 \times 10^{5}\right)$, and noncancerous NIH-3T3 $\left(6 \times 10^{4}\right)$ and VH10 $\left(1 \times 10^{5}\right)$ cells, were incubated for 24, 48 and $72 \mathrm{~h}$, then harvested, washed in PBS, centrifuged at $1,500 \times \mathrm{g}$ for $10 \mathrm{~min}$ at $4^{\circ} \mathrm{C}$ and lysed with $50 \mu \mathrm{l}$ of lysis solution $(10 \mathrm{mmol} / \mathrm{l}$ Tris, $10 \mathrm{mmol} / \mathrm{l}$ ethylenediaminetetraacetic acid and $0.5 \%$ Triton X-100) supplemented with proteinase $\mathrm{K}(1 \mathrm{mg} / \mathrm{ml})$. Samples were incubated at $37^{\circ} \mathrm{C}$ for $1 \mathrm{~h}$ and then heated at $70^{\circ} \mathrm{C}$ for $10 \mathrm{~min}$. Following lysis, $2.5 \mu \mathrm{l}$ RNase $(200 \mu \mathrm{g} / \mathrm{ml})$ was added followed by repeated incubation at $37^{\circ} \mathrm{C}$ for $1 \mathrm{~h}$. The samples were subjected to electrophoresis at $40 \mathrm{~V}$ for $2.5 \mathrm{~h}$ in $2 \%$ agarose gel with ethidium bromide. As a positive control, L1210 cells were incubated with $6 \mu \mathrm{mol} / 1$ cis-platin (Sigma-Aldrich, St. Louis, MO, USA) for $24 \mathrm{~h}$ and processed according to the protocol described above. Separated DNA fragments were visualized using an Ultra-Lum Electronic UV transilluminator at $254 \mathrm{~nm}$.

Caspase 3 activity. Caspase 3 activity was analyzed using Caspase 3 colorimetric assay kit (CaspACE ${ }^{\mathrm{TM}}$ Assay system Colorimetric; Promega Corporation, Madison, WI, USA). The cells were treated with $\mathrm{Cu}$ (II) complexes (1-100 $\mu \mathrm{mol} / \mathrm{l})$ for $60 \mathrm{~h}$. Cell lysates were isolated and caspase 3 activity was measured according to the manufacturer's protocol. Protein concentrations were determined by the Bradford method as previously described by Buzdar et al (18). Samples were added to the reaction mixtures containing colorimetric substrate peptides specific for caspase $3 \mathrm{~N}$-acetyl-Asp-Glu-Val-Asp-p-nitroanilin (Ac-DEVD-pNA). The plate was incubated at $37^{\circ} \mathrm{C}$ for 2,4 , 6 and $8 \mathrm{~h}$. Each sample containing $200 \mu \mathrm{g}$ proteins was incubated with caspase 3 substrate, Ac-DEVD- $p$ NA, in the reaction buffer in a 96-well flat bottomed microplates. Absorbance was read at $405 \mathrm{~nm}$ using a spectrophotometric microplate reader (Humareader; HUMAN Diagnostics Worldwide, Wiesbaden, Germany).

DNA constructs. The pCMVHA ubiquitin construct [ubiquitin DNA sequence ligated into pCMV-hemagglutinin (Ha) vector; Clontech Laboratories, Inc., Mountain View, CA, USA] and pCMVcMyc ubiquitin construct (ubiquitin DNA sequence ligated into the pCMV-Myc vector; Clontech Laboratories, Inc.) were prepared at the Institute of Chemical Technology (Prague, Czech Republic) by Dr Markéta Landová and Dr Anna Lounková,. They were allowed to express ubiquitin fused to either the c-Myc or HA epitope tag for detection with the appropriate antibodies: mouse monoclonal anti-HA tag antibody (cat. no. ab18181); mouse monoclonal anti-c-myc antibody (cat. no. ab11917); dilutions 1:5,000; purchased from Abcam (Cambridge, UK). The pRK5-HA ubiquitin construct was provided by Addgene, Inc. (Cambridge, MA, USA), used according to previous studies by Chung et al (19) and Lim et al (20). c-Myc and HA have been previously characterized and are highly immunoreactive tags, thus are easily detected via western blotting.

Spectrophotometric measurement of caspase 8/9 activities. The Caspase Glo 8/9 Assay kit was used to measure caspase 8 and 9 activities according to the manufacturer's protocol (Promega Corporation). Cells were incubated with complexes 1-4 (1-100 $\mu \mathrm{mol} / \mathrm{l}$ ) for $60 \mathrm{~h}$. Briefly, $100 \mu \mathrm{l}$ Caspase Glo ${ }^{\mathrm{TM}} 8$ reagent 
for measuring caspase 8 activity, containing specific substrate Ac-LETD-pNA (N-acetyl-Leu-Glu-Thr-Asp-p-nitroanilin) and $100 \mu \mathrm{l}$ Caspase $\mathrm{Glo}^{\mathrm{TM}} 9$ reagent for measuring caspase 9 activity, containing the specific substrate Ac-LEHD-pNA (N-acetyl-Leu-Glu-His-Asp-p-nitroanilin), were added to the test tube with $100 \mu \mathrm{l}$ cell suspension containing 50,000 cells. The cells were then mixed, and the luminescent signal was measured after $0,10,30,60,90$ and 120 min in the GloMax ${ }^{\circledR}$-96 Luminometer (Turner Biosystems, Sunnyvale, CA, USA).

Detection of anti- and proapoptotic proteins by western blotting. Cells were grown in 6-well microplates and treated with $\mathrm{Cu}$ (II) complexes ( $\mathrm{IC}_{50}$ concentration) for different time periods $(24,48$ and $72 \mathrm{~h}$ ). Subsequent to treatment, cells were resuspended in lysis buffer and boiled for $3 \mathrm{~min}$ at $100^{\circ} \mathrm{C}$. Proteins in the cell lysates were separated using 10\% SDS-PAGE and blotted onto nitrocellulose membranes (Bio-Rad Laboratories, Inc.). Subsequent to blocking overnight in 5\% milk, the membranes were incubated with mouse monoclonal anti-cytochrome $c$ (cyt c; 1:500; cat. no. sc-13560), mouse monoclonal anti-Bax (1:500; cat. no. sc-7480) or rabbit polyclonal Bcl-2 (1:500; cat. no. sc-492) antibodies (Santa Cruz Biotechnologies, Inc., Dallas, TX, USA) for $3 \mathrm{~h}$ at $4^{\circ} \mathrm{C}$. The membranes were then washed and incubated for $1 \mathrm{~h}$ with the appropriate anti-mouse (cat. no. sc-2005) or anti-rabbit (cat. no. sc-2004) horseradish peroxidase-conjugated secondary antibody (1:4,000 or 1:5,000 respectively; Santa Cruz Biotechnology, Inc.). Immunoreactive bands were visualized with SuperSignal West Femto and images were captured using the Alliance 4.7 UVITEC Imaging system.

Transfection and the proteasome activity. HT-29 human colon cancer cells and human healthy HEK-293T cells were seeded into a single 6-well cell culture plate. Transfection with the aforementioned plasmids was conducted using FuGene HD reagent (Promega Corporation) according to manufacturer's instructions. After 4-5 h, the medium was changed and $\mathrm{Cu}$ (II) complexes were added to the final concentration of the $\mathrm{IC}_{50}$. After $24 \mathrm{~h}$, cells were washed with PBS. Non-treated cells were used as a negative control and cells treated with the commercially available inhibitor of proteasome MG132 (2.5 mol/l; Sigma-Aldrich) were used as a positive control.

Statistical analysis. Results are expressed as the mean \pm standard deviation three separate experiments (each experiment was performed with five replicates). GraphPad Prism 6.0 (GraphPad Software, Inc., La Jolla, CA, USA). The data without deviation from normality were evaluated using two-way analysis of variance with Tukey test (for caspase 3 ) or Dunnett's T3 (for caspases 8 and 9) as post-hoc tests. $\mathrm{P}<0.05$ was considered to indicate a statistically significant difference.

\section{Results}

Cytotoxicity analysis. Effect of tested Cu (II) complexes (1-4) on the HT-29 human colon carcinoma, NIH-3T3 mouse noncancerous and the VH10 human noncancerous fibroblast cell lines was evaluated using the MTT assay and a direct counting of viable cells by the trypan blue exclusion assay during $72 \mathrm{~h}$ of treatment. The concentration range of the complexes was $0.001-100 \mu \mathrm{mol} / 1$.

Table I presents the effects of different concentrations of $\mathrm{Cu}$ (II) complexes on the tested cell lines. The results of the current study indicate the cytotoxic effects of $\mathrm{Cu}$ (II) complexes on the HT-29 cell line. $\mathrm{IC}_{50}$ values were reduced with treatment duration. Complexes 3 and 4 exhibited the highest efficacy against HT-29 cells.

Of the healthy cell lines (Table I) the most sensitive noncancerous cells were identified to be NIH-3T3 when compared with VH10. VH10 cells were sensitive only following $48 \mathrm{~h}$ of exposure (complexes 1 and 4).

In order to ascertain the influence of $\mathrm{Cu}$ (II) ions and free ligands on cell proliferation, $\mathrm{CuSO}_{4} .5 \mathrm{H}_{2} \mathrm{O}$, salicylaldehyde and L-glutamic acid (0.001-100 $\mu \mathrm{mol} / \mathrm{l})$ were additionally tested. All tested compounds exhibited an $\mathrm{IC}_{50}>100 \mu \mathrm{mol} / 1$.

Fluorescence microscopy. Analysis of the morphological alterations of individual actin filaments was conducted using fluorescence microscopy to identify a correlation with filament bending mechanics. In order to investigate the structural alterations of the F-actin filaments making up the actin cytoskeleton, fluorescent phalloidine was used to mark the F-actin filaments of the HT-29 human colon carcinoma cells, NIH-3T3 mouse noncancerous fibroblast cells and VH10 human noncancerous fibroblast cells treated with $\mathrm{Cu}$ (II) complexes at concentrations of $\mathrm{IC}_{50}$ for $24 \mathrm{~h}$ (Fig. 1).

In the control non-treated cells, actin filaments were without morphological changes. On the other hand, subsequent to treatment with $\mathrm{Cu}$ (II) complexes, cytoskeletal alterations were observed, with breakdown of the actin network. These results suggested that an $\mathrm{IC}_{50}$ concentration of the $\mathrm{Cu}$ (II) complexes resulted in damage to the cytoskeletal network of cancer cells and may be associated with a reduction in mobility. However, the actin fibers of noncancerous cells (NIH-3T3 and VH10) were comparable with those of control cells (without complexes), exhibiting no cytoskeletal morphological alterations.

Detection of apoptosis in HT-29 cells. In order to distinguish the type of cell death induced by $\mathrm{Cu}$ (II)-complexes in HT-29 human colon carcinoma cells, in NIH-3T3 mouse noncancerous fibroblast cells and in VH10 human noncancerous fibroblast cells (Fig. 2), electrophoretic analysis was used. A total of 4 concentrations of the complexes were incubated with the cells for $72 \mathrm{~h}$. Cell nuclei of HT-29 cells collapsed and disintegrated, indicating that apoptosis was induced by $\mathrm{Cu}$ (II) complexes. In samples exposed to complexes 1 (0.1, $1,10$ and $50 \mu \mathrm{mol} / \mathrm{l}), 2(1,10,50$ and $100 \mu \mathrm{mol} / \mathrm{l}), 3(0.01,1$, 10 and $50 \mu \mathrm{mol} / \mathrm{l})$ and $4(0.01,0.1,1$ and $10 \mu \mathrm{mol} / \mathrm{l})$, apoptosis was identified following $72 \mathrm{~h}$ of incubation.

To validate the apoptotic type of death induced by $\mathrm{Cu}$ (II) complexes (0.1-100 $\mu \mathrm{mol} / \mathrm{l})$ in HT-29 human colon carcinoma cells, caspase 3 activity was examined following $60 \mathrm{~h}$ of exposure. The activity of caspase 3 was measured every $2 \mathrm{~h}$ during $8 \mathrm{~h}$ incubation with the complex. It was identified that the $\mathrm{Cu}$ (II) complexes induced an increase in activity of caspase 3 (Fig. 3). As a positive control, L1210 murine leukemia cells influenced with cis-platin were used $(6 \mu \mathrm{mol} / \mathrm{l})$. 
Table I. Inhibitory effects of $\mathrm{Cu}$ (II) complexes on the proliferation of human cancer (HT-29) and noncancerous cells (NIH-3T3 and VH10).

\begin{tabular}{|c|c|c|c|c|c|c|c|c|c|}
\hline \multirow[b]{2}{*}{ Complex } & \multicolumn{3}{|c|}{ HT-29 $\left(\mathrm{IC}_{50}\right)$} & \multicolumn{3}{|c|}{ NIH-3T3 $\left(\mathrm{IC}_{50}\right)$} & \multicolumn{3}{|c|}{ VH10 $\left(\mathrm{IC}_{50}\right)$} \\
\hline & $24 \mathrm{~h}$ & $48 \mathrm{~h}$ & $72 \mathrm{~h}$ & $24 \mathrm{~h}$ & $48 \mathrm{~h}$ & $72 \mathrm{~h}$ & $24 \mathrm{~h}$ & $48 \mathrm{~h}$ & $72 \mathrm{~h}$ \\
\hline 1 & $10.00 \pm 0.32$ & $4.00 \pm 0.12$ & $1.00 \pm 0.05$ & $10.00 \pm 0.25$ & $25.00 \pm 0.34$ & $0.550 \pm 0.001$ & $>100$ & $10.00 \pm 0.36$ & $18.5 \pm 0.10$ \\
\hline 2 & $31.00 \pm 0.28$ & $25 \pm 0.42$ & $6.00 \pm 0.11$ & $50.00 \pm 0.48$ & $>100$ & $1.00 \pm 0.06$ & $>100$ & $>100$ & $10.00 \pm 0.35$ \\
\hline 3 & $0.17 \pm 0.06$ & $13.00 \pm 0.25$ & $0.007 \pm 0.002$ & $>100$ & $5.50 \pm 0.34$ & $1.50 \pm 0.02$ & $>100$ & $>100$ & $30.50 \pm 0.21$ \\
\hline 4 & $0.57 \pm 0.01$ & $0.07 \pm 0.01$ & $0.17 \pm 0.01$ & $0.075 \pm 0.009$ & $30.00 \pm 0.48$ & $1.50 \pm 0.07$ & $>100$ & $34.5 \pm 0.24$ & $40.0 \pm 0.33$ \\
\hline
\end{tabular}

Cells were treated with copper complexes (1-4) at the concentration of $\mathrm{IC}_{50}(\mu \mathrm{mol} / \mathrm{ml})$ for 24,48 and $72 \mathrm{~h}$ and the cell death was detected by the trypan blue assay and the 3-(4,5-dimethylthiazol-2-yl)-2,5-diphenyltetrazolium bromide test. Results are expressed as the mean \pm standard deviation from three independent experiments.
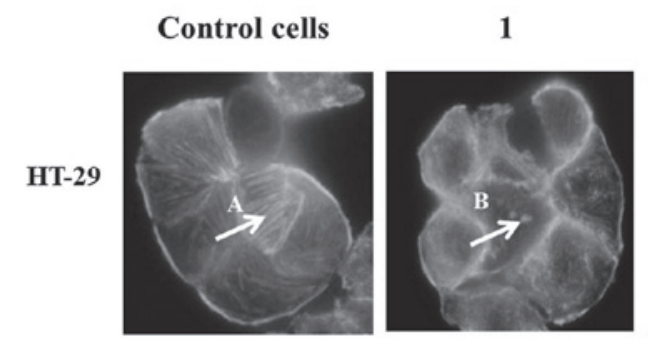

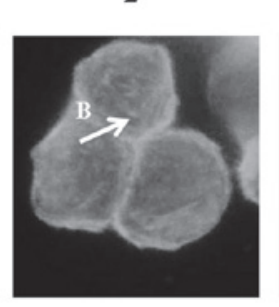

3
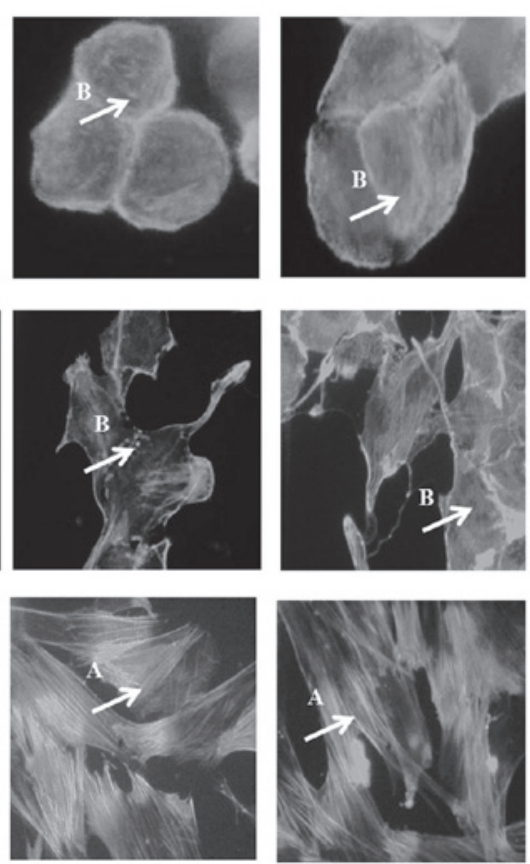
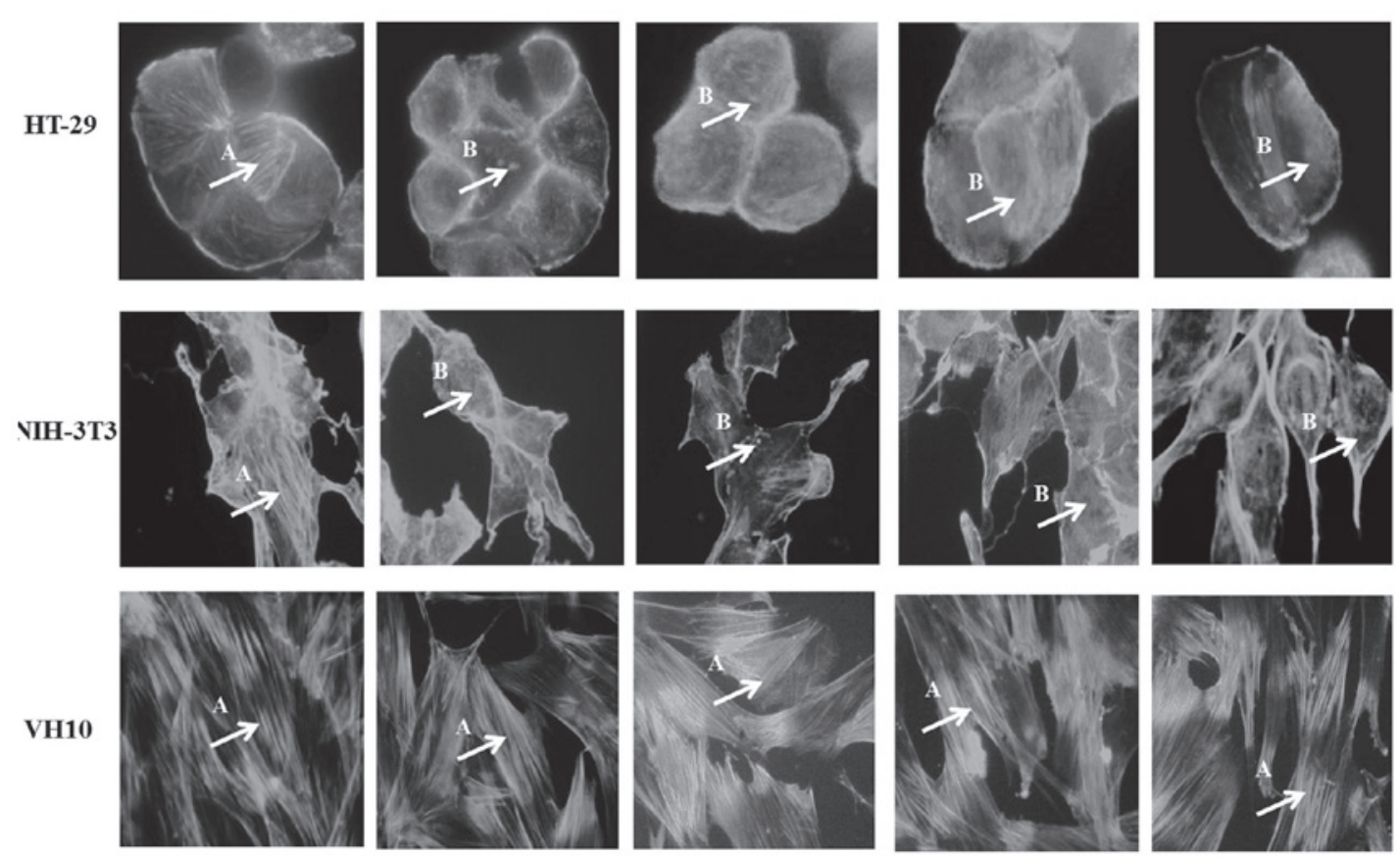

Figure 1. HT-29, NIH-3T3 and VH10 cells treated with the $\mathrm{Cu}$ (II) complexes (1, 2, 3 and 4) at $\mathrm{IC}_{50}$ concentrations for $24 \mathrm{~h}$. The green color indicates the actin filaments stained with fluorescent phalloidin. In the control cells (without complexes) there were no morphological alterations observed in the fibers. A indicates intact fibers and B indicates damaged fibers.

Apoptosis can be triggered through two signaling pathways, the extrinsic (with active caspase 8) and intrinsic mitochondria-dependent (with active caspase 9) pathways (21). The aim of the curent study was to identify which of these pathways is activated by the $\mathrm{Cu}$ (II) complexes. Therefore, the activity of caspase $8 / 9$ was monitored.

Activity of caspase 8/9 in HT-29 cells. HT-29 human colon carcinoma cells were treated with $\mathrm{Cu}$ (II) complexes (0.1-100 $\mu \mathrm{mol} / \mathrm{l})$ for $60 \mathrm{~h}$. To detect caspase $8 / 9$ activities, a luminometric assay was used. Activation of caspase 9 observed with exposure to complexes 2, 3 and 4 (Fig. 4) and activation of caspase 8 with exposure to complex 1 (Fig. 4). The results indicate that complexes 2,3 and 4 are able to induce the mitochondria-dependent pathway of apoptosis in
HT-29 cells, while complex 1 activates the extrinsic pathway of apoptosis.

Levels of anti/pro-apoptotic proteins in HT-29 cells and release of cyt $c$. To further investigate the mechanism of apoptosis, the expression levels of Bcl-2 and Bax proteins were measured, and the release of cyt $\mathrm{c}$ was analyzed by western blotting subsequent to exposure of cells to the $\mathrm{Cu}$ (II) complexes $\left(\mathrm{IC}_{50}\right)$ for $60 \mathrm{~h}$ (Fig. 5). The anti-apoptotic protein Bcl-2 was not detected in HT-29 cells. In contrast, the quantity of the pro-apoptotic protein Bax was increased following treatment with complexes 2, 3 and 4 , and this increase was time-dependent, with the maximum at $6 \mathrm{~h}$ (complexes 2 and 3 ) and $60 \mathrm{~h}$ (complex 4). Complex 1 alone did not induce Bax protein expression. The release of cyt $\mathrm{c}$ from mitochondria was 


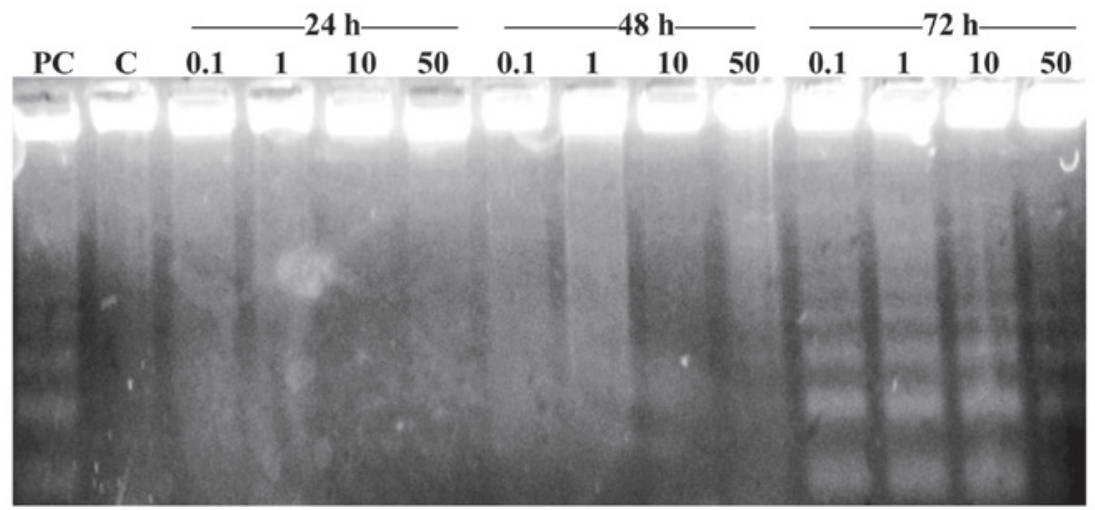

Figure 2. Apoptotic DNA fragmentation, visualised by the DNA laddering assay of HT-29 cells treated with Cu (II) complexes (1-4) for 24,48 and 72 h. PC cells (L1210 cells treated with $6 \mu \mathrm{mol} / 1$ cis-platin) and C cells (non-treated) were included for comparison. The concentrations of $\mathrm{Cu}$ (II) used were $0.1,1$, 10 and $50 \mu \mathrm{mol} / 1$. PC, positive control; C, control.
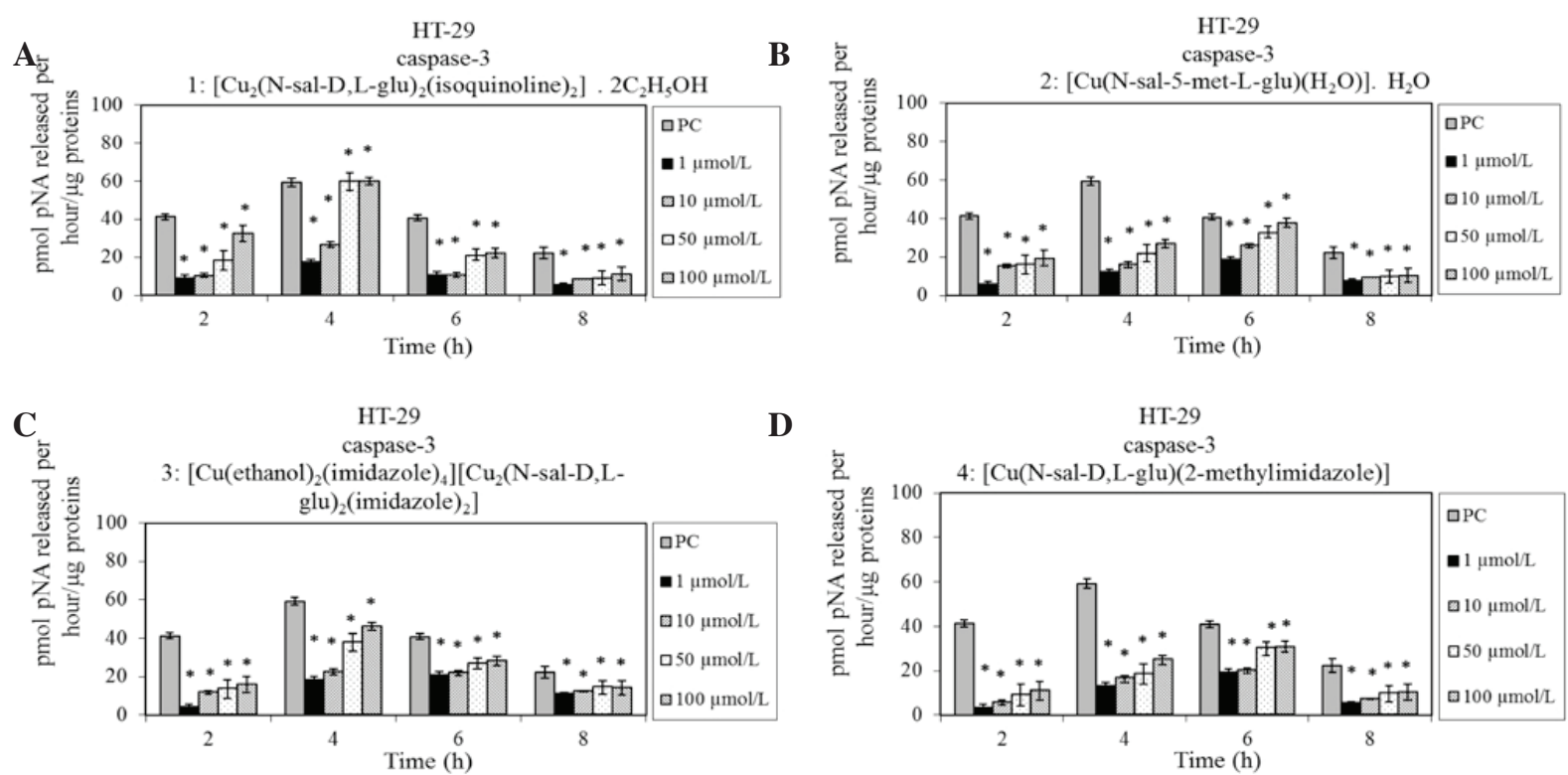

Figure 3. Activity of caspase 3 in HT-29 human colon carcinoma cells exposed to Cu (II) complexes (A) 1, (B) 2 , (C) 3 and (D) 4 (1-100 $\mu$ mol/1). As the PC, cis-platin was used in L1210 cells $(6 \mu \mathrm{mol} / \mathrm{l})$. The concentrations of $\mathrm{Cu}$ (II) used were 1, 10,50 and $100 \mu \mathrm{mol} / 1$. All data are presented as the mean \pm standard deviation of triplicate results. ${ }^{*}<0.05$ vs. PC. pNA, para-nitroaniline; PC, positive control.

also investigated. The elevation of cyt $\mathrm{c}$ levels by complex 4 was time-dependent with the maximum at $60 \mathrm{~h}$. By contrast, complexes 2 and 3 induced the maximal cyt $\mathrm{c}$ release at 3 h-incubation. No cyt $\mathrm{c}$ was detected in HT-29 cells influenced with complex 1, suggesting that this $\mathrm{Cu}$ (II) complex activated the extrinsic pathway of apoptosis.

Effect of $C u(I I)$ complexes on proteasome activity. The ubiquitin-proteasome system serves an important role in cell growth and apoptosis and has been demonstrated as a novel target for cancer therapy (22). The inhibition of the tumor proteasomal activity results in the accumulation of ubiquitinated proteins, the proteasome target proteins $\mathrm{p} 27$ and Bax and ubiquitinated form of inhibitor of $\kappa \mathrm{B}-\alpha$, a natural proteasome substrate, followed by the induction of apoptosis. The ability of $\mathrm{Cu}$ (II) complexes to inhibit the proteasome was investigated. Proteasome inhibition was detected by western blot analysis in HT-29 human colon carcinoma cells (Fig. 6A) and HEK-293T human healthy embryonal cells (Fig. 6B). Cells were transfected with plasmid DNA (pCMVHA ubiquitin) and treated with the $\mathrm{Cu}$ (II) complexes at the $\mathrm{IC}_{50}$ concentration $(\mu \mathrm{mol} / \mathrm{l})$ for $24 \mathrm{~h}$. No ubiquitin bands $(10 \mathrm{kDa})$ were detected in the samples, and were not detected in the sample containing the commercially used inhibitor of proteasome MG132 (Fig. 6A). Therefore, alternative DNA plasmids (pCMVcMyc ubiquitin and pRK-5HA Ubiquitin) were used, however the results were the same. In order to examine whether the plasmid DNAs used were correct, healthy embryonic HEK-293T were transfected with the first plasmid DNA construct (pCMVHA ubiquitin) and these cells were treated with $\mathrm{Cu}$ (II) complexes under the same conditions as for the HT-29 cells. Fig. 6B indicates that $\mathrm{Cu}$ (II) complexes inhibited the proteasome, and a ubiquitin band (10 kDa) was detecte in all samples (1-4) containing $\mathrm{Cu}$ (II) complexes. Ubiquitin levels in the HEK-293T cells were comparable with cells incubated with the commercially used inhibitor of proteasome MG132 (line C2). The results 
HT-29

caspase 8

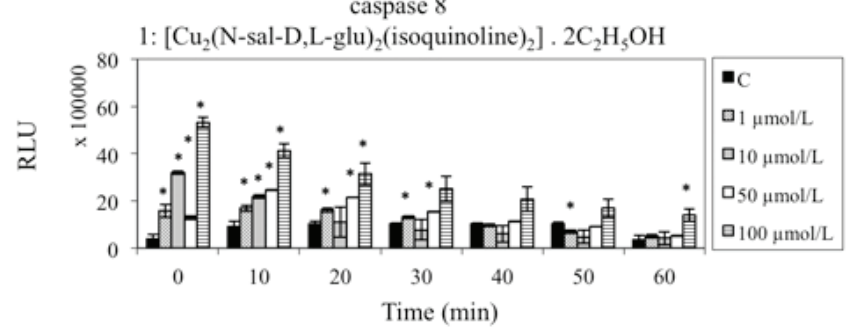

HT-29

caspase 8

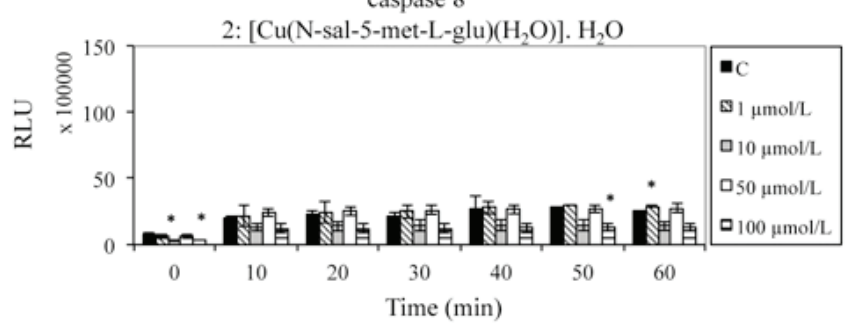

HT-29

caspase 8

3: $\left[\mathrm{Cu}(\text { ethanol })_{2}(\text { imidazole })_{4}\right]\left[\mathrm{Cu}_{2}(\mathrm{~N} \text {-sal-D,L-glu })_{2}(\text { imidazole })_{2}\right]$
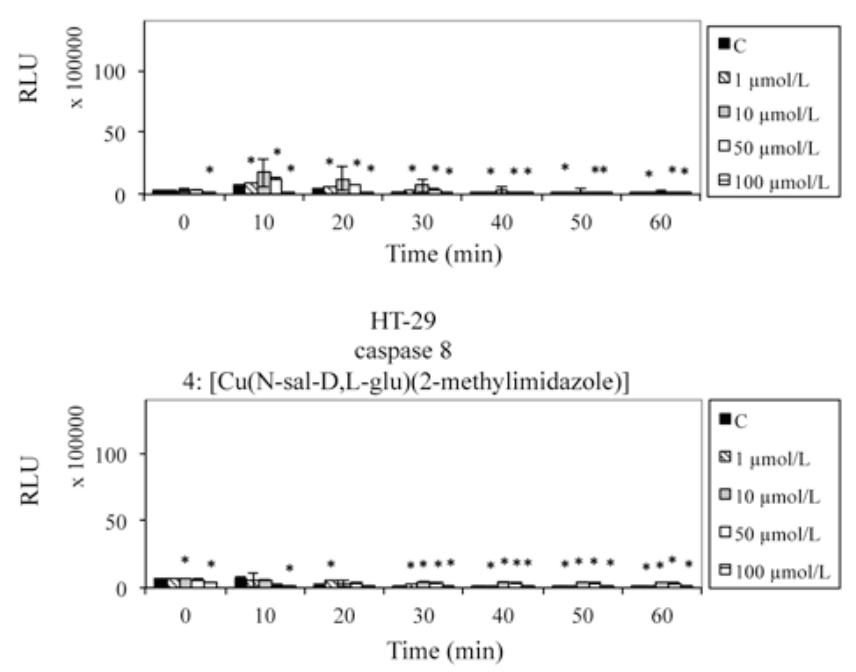
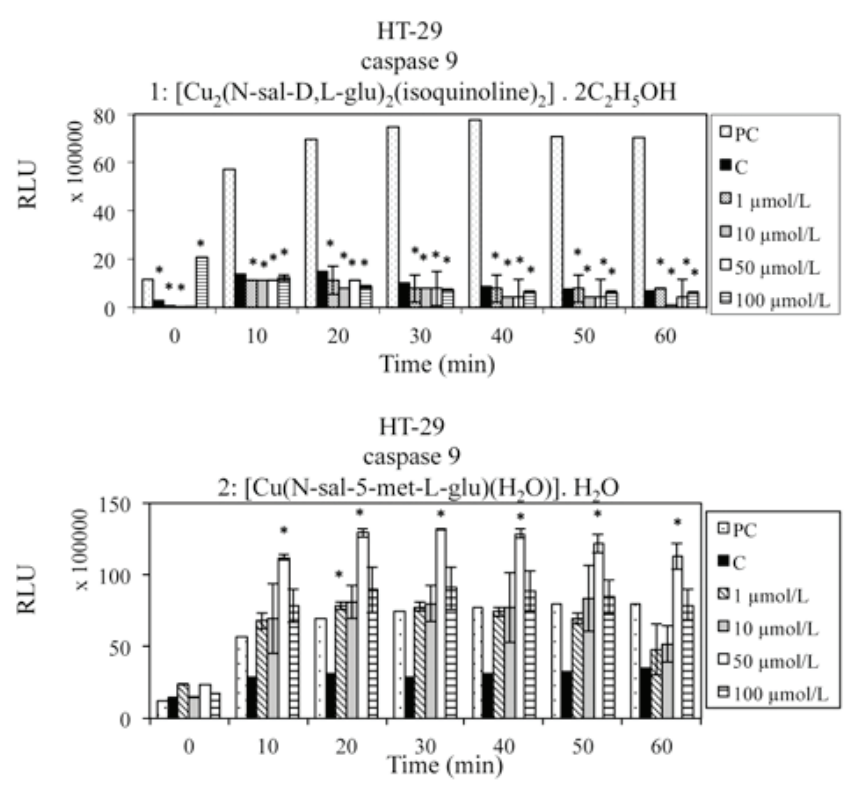

HT-29

caspase 9

3: $\left.\left[\mathrm{Cu}(\text { ethanol })_{2}(\text { imidazole })_{4}\right]\left[\mathrm{Cu}_{2}(\mathrm{~N} \text {-sal-D,L-glu })_{2} \text { (imidazole }\right)_{2}\right]$

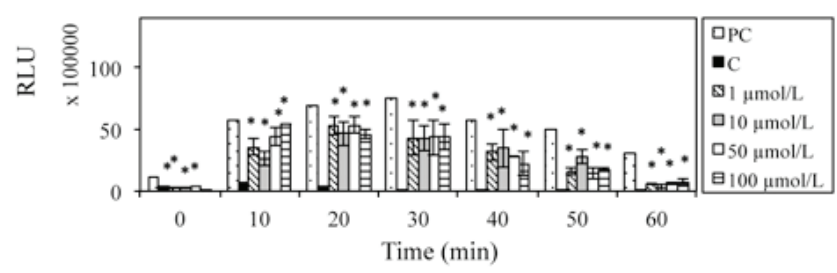

HT-29

caspase 9

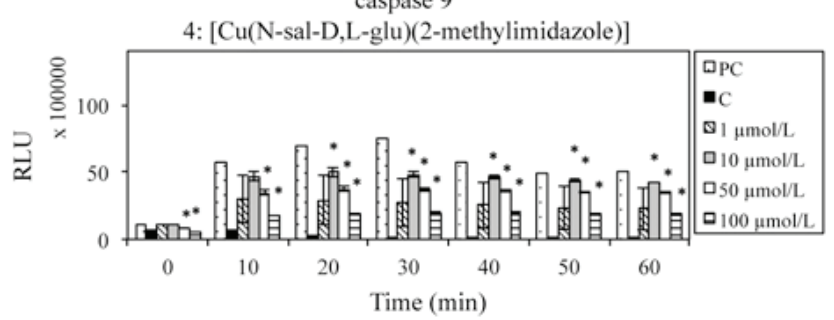

Figure 4. Activities of caspase 8/9 in HT-29 human colon carcinoma cells exposed to Cu (II) complexes (1-100 $\mu$ mol/l). As the PC, cis-platin was used in L1210 cells $(6 \mu \mathrm{mol} / \mathrm{l})$ and the C HT-29 human carcinoma cells were not treated with the Cu (II) complexes. The concentrations of Cu (II) used were $1,10,50$ and $100 \mu \mathrm{mol} / 1$. All data are presented as the mean \pm standard deviation of triplicate results. ${ }^{*} \mathrm{P}<0.05$ vs. C. RLU, relative luminescent units; PC, positive control; C, control.

suggest that HT-29 cells are not suitable for transfection with the DNA constructs used in the current experiment.

\section{Discussion}

A total of 4 Schiff base $\mathrm{Cu}$ (II) complexes were investigated in HT-29 human colon carcinoma cells and VH10 and NIH-3T3 noncancerous cells. The most effective $\mathrm{Cu}$ (II) complex against HT-29 cells (with an imidazole ligand in its structure) had an $\mathrm{IC}_{50}$ of $0.007 \mu \mathrm{mol} / \mathrm{l}(0.008 \mu \mathrm{g} / \mathrm{ml})$ subsequent to $72 \mathrm{~h}$ incubation with cells. In order to improve understanding of the biological effects of novel potential anticancer drugs, it is important to study the molecular mechanisms involved. Two types of caspases have been reported to serve key roles in mediating apoptosis: Initiator caspases, caspases 2, 8, 9 and 10; and effector caspases, caspases 3,6 and 7. Activation of initiator caspases is required to activate specific effector caspases that subsequently proteolytically degrade a host of intracellular proteins to mediate the cell death program/apoptosis. In the current study, the types of apoptotic pathway activated by tested Schiff base $\mathrm{Cu}$ (II) complexes were reported. The only complex inducing the extrinsic apoptotic pathway was complex 1 , which contains isoquinoline as a ligand. The remaining complexes activated the intrinsic (mitochondrial) pathway of apoptosis.

Rajalakshmi et al (23) tested two copper (II) complexes $\left(\left[\mathrm{Cu}(\text { bitpy })_{2}\right]\left(\mathrm{ClO}_{4}\right)_{2} \bullet 2 \mathrm{H}_{2} \mathrm{O} ;[\mathrm{Cu}(\right.$ bitpy $)($ phen $\left.)]\left(\mathrm{NO}_{3}\right)_{2} \bullet 3 \mathrm{H}_{2} \mathrm{O}\right)$. It was identified that these two complexes $(10 \mu \mathrm{mol} / \mathrm{l}) \mathrm{acti}-$ vated the intrinsic pathway of apoptosis in NIH-3T3 and MG63 cells. Thati et al (24) additionally identified that the intrinsic pathway of apoptosis was activated in A498 and 


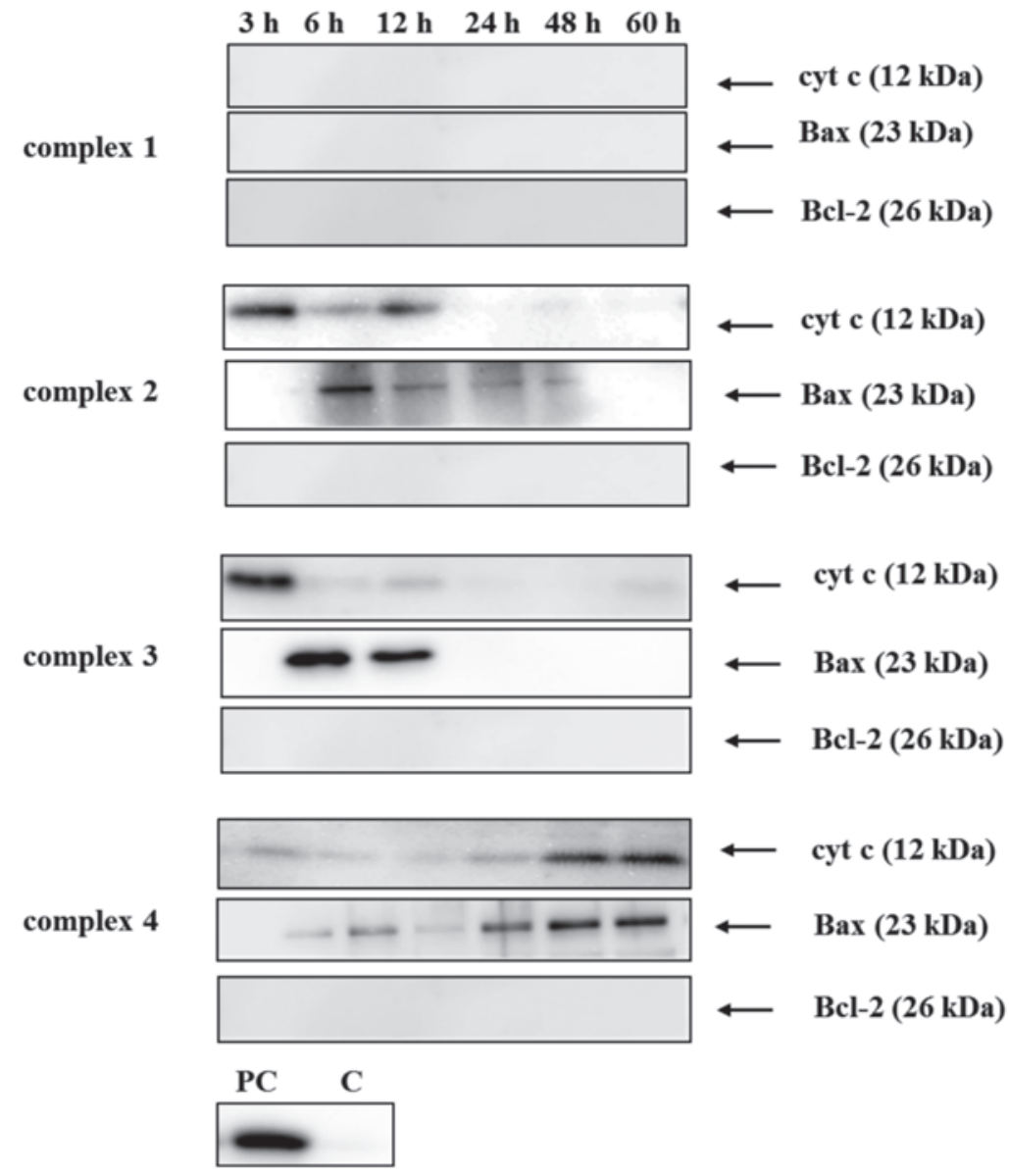

Figure 5. Western blot analysis of the anti-apoptotic Bcl-2 protein, pro-apoptotic Bax protein and cyt c following 60 -h exposure to $\mathrm{Cu}$ (II) complexes at $\mathrm{IC}_{50}$ concentrations. As the PC, cis-platin was used in L1210 cells ( $6 \mu \mathrm{mol} / \mathrm{l})$ and the C HT-29 human carcinoma cells were not treated with the Cu (II) complexes. Cyt c, cytochrome $c$; PC, positive control; C, control.

A

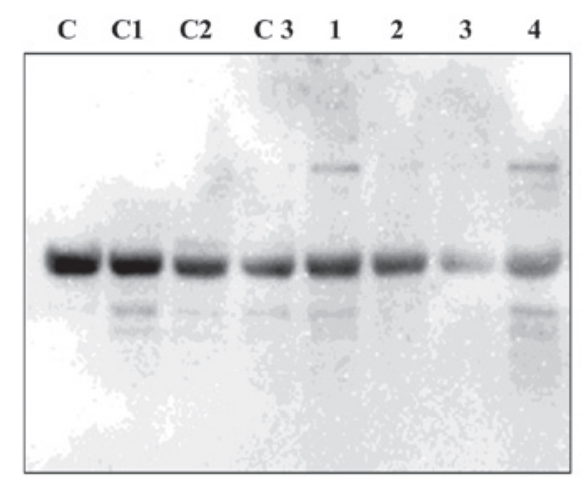

B

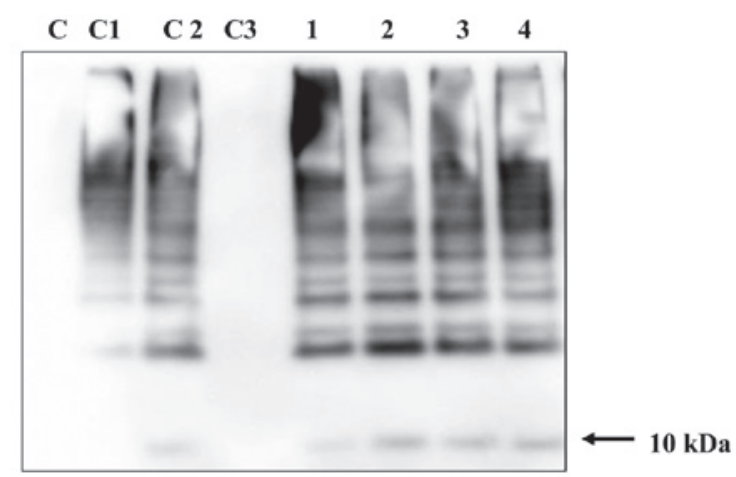

Figure 6. Detection of proteasome inhibition in (A) HT-29 and (B) HEK-293T cells by western blot analysis subsequent to treatment with Cu (II) complexes at the $\mathrm{IC}_{50}$ concentration for $24 \mathrm{~h}$. The cell groupings were as follows: $\mathrm{C}$, no transfection, not treated with the commercial inhibitor $\mathrm{MG} 123$ or with $\mathrm{Cu}$ (II) complexes; $\mathrm{C} 1$, underwent transfection, not treated with the commercial inhibitor MG123 or with Cu (II) complexes; C2, underwent transfection, treated commercial inhibitor MG123, not treated with Cu (II) complexes; C3, cells without transfection, treated with the commercial inhibitor MG123, not treated with $\mathrm{Cu}$ (II) complexes; 1, 2, 3 and 4, underwent transfection, treated with $\mathrm{Cu}$ (II) complexes at the $\mathrm{IC}_{50}$ concentration for $24 \mathrm{~h}$.

HepG2 cells as a result of exposure to the $\mathrm{Cu}$ (II) complex bis [phenanthroline-4-methylcoumarin-6,7-dioxacetatocopper (II)] at concentrations of 12.5 and $25 \mu \mathrm{mol} / 1$, however not at the lower concentration $(6.25 \mu \mathrm{mol} / \mathrm{l})$. They detected increased activities of caspase 3 and 9 following $24 \mathrm{~h}$ incubation (24).
An additional $\mathrm{Cu}(\mathrm{II})$ complex $\left[\mathrm{Cu}\left(\mathrm{BMA}^{\mathrm{C}} \mathrm{Cl}_{2}\right] \bullet\left(\mathrm{CH}_{3} \mathrm{OH}\right)\right.$ [BMA $=\mathrm{N}, \mathrm{N}$-bis (benzimidazol-2-yl-methyl) amine] also activated apoptosis through the intrinsic (mitochondrial) pathway by activation of caspases 9 and 3 subsequent to its $48 \mathrm{~h}$ incubation with HeLa cells. Enzyme activities were increased in a dose-dependent manner (25). 
The current study identifed that complex 1 alone, with the isoquinoline ligand, activated the extrinsic pathway of apoptosis. All other $\mathrm{Cu}$ (II) complexes tested in the present study activated the intrinsic pathway of apoptosis. The intrinsic pathway of apoptosis results in mitochondrial dysfunction, and mitochondria are semi-autonomous organelles that serve essential roles in cellular metabolism and programmed cell death pathways (26).

Major resistance mechanisms of mitochondria that are regulated by Bcl-2 family proteins and potential strategies to circumvent the resistance have additionally been examined (27). In the current study, it was identified that $\mathrm{Cu}$ (II) complexes inhibited the release of Bcl-2 (antiapoptotic) protein and induced the release of Bax (proapoptotic) protein. Liu et al (28) exposed GBM cells to disulfiran plus $\mathrm{Cu}$ (II) $(1 \mu \mathrm{mol} / \mathrm{l})$ for $48 \mathrm{~h}$ and observed the release of Bax protein.

Proliferation and apoptosis pathways are tightly regulated in a cell by the ubiquitin-proteasome system (UPS). Alterations in the UPS may result in cellular transformation or additional pathological conditions. A previous study suggested that $\mathrm{Cu}$ (II) complexes can inhibit proteasome activity and induce apoptosis in certain human cancer cells (29). However, using the cancer cell line HT-29, the current study was unable to confirm these results.

Schiff base $\mathrm{Cu}$ (II) complexes were able to suppress tumor cell growth via the direct inhibition of proteosomal activity. Zhang et al (30) studied the complex [Cu(tssb)(phen) $\left.\mathrm{H}_{2} \mathrm{O}\right] \cdot \mathrm{C}_{2} \mathrm{H}_{5} \mathrm{OH} \bullet 0.5 \mathrm{H}_{2} \mathrm{O}\left(\mathrm{H}_{2} \mathrm{tssb}=\right.$ Schiff base derived from salicylaldehyde and taurine, phen=1,10-phenanthroline) and confirmed that it inhibits the activity of purified $20 \mathrm{~S}$ and $26 \mathrm{~S}$ proteasome in human breast cancer MDA-MB-231 and leukemia Jurkat T cells.

A study by Xiao et al (31) used a newly synthesized L-glutamine-containing copper complex (L-glutamine-o-vanillin-copper) on tumor cells. This copper complex had proteasome-inhibitory activity in human breast cancer and leukemia cells (31).

With an increased understanding of the intrinsic and extrinsic pathways of apoptosis in recent years, novel approaches of targeting the apoptotic pathways have been tested in pre-clinical and clinical models (32). The results of the current study, together with those from previous studies suggest that $\mathrm{Cu}$ (II) complexes containing Schiff bases have potential as novel anticancer drugs.

\section{Acknowledgements}

The current study was conducted with the financial support of the Ministry of Education (grant no. VEGA 1/0752/13), the Operational Programme Prague (grant no. CZ.2.16/3.1.00/2450 3), NPU I (LO1601 grant no. MSMT-43760/2015). We wish to thank to Luboš Kuračka for his assistance with figure preparations.

\section{References}

1. Nielsen DL, Palshof JA, Larsen FO, Jensen BV and Pfeiffer P: A systematic review of salvage therapy to patients with metastatic colorectal cancer previously treated with fluorouracil, oxaliplatin and irinotecan +/- targeted therapy. Cancer Treat Rev 40: 701-715, 2014.
2. Funakoshi T,Latif A and Galsky MD: Safety and efficacy of addition of VEGFR and EGFR-family oral small-molecule tyrosine kinase inhibitors to cytotoxic chemotherapy in solid cancers: A systematic review and meta-analysis of randomized controlled trials. Cancer Treat Rev 40: 636-647, 2014.

3. Lyman GH, Abella E and Pettengell R: Risk factors for febrile neutropenia among patients with cancer receiving chemotherapy: A systematic review. Crit Rev Oncol Hematol 90: 190-199, 2014.

4. Miltenburg NC and Boogerd W: Chemotherapy-induced neuropathy: A comprehensive survey. Cancer Treat Rev 40: 872-882, 2004.

5. Damia G and Garattini S: The pharmacological point of view of resistance to therapy in tumors. Cancer Treat Rev 40: 909-916, 2014.

6. Zayed EM,Zayed MA and El-Desawy M: Preparation and structure investigation of novel Schiff bases using spectroscopic, thermal analyses and molecular orbital calculations and studying their biological activities. Spectrochim Acta A Mol Biomol Spectrosc 134: 155-164, 2015.

7. Emam SM, Sayed IETE and Nassar N: Transition metal complexes of neocryptolepine analogues. Part I: Synthesis, spectroscopic characterization and in vitro anticancer activity of copper(II) complexes. Spectrochim Acta A Mol Biomol Spectrosc 138: 942-953, 2015.

8. Santini C, Pellei M, Gandin V, Porchia M, Tisato F and Marzano C: Advances in copper complexes as anticancer agents. Chem Rev 114: 815-862, 2014.

9. Creaven BS, Duff B, Egan DA, Kavanaghc K, Rosaird G, Thangella VR and Walsh M: Anticancer and antifungal activity of copper(II) complexes of quinolin-2(1H)-one-derived Schiff bases. Inorganica Chim Acta 363: 4048-4058, 2010.

10. Khoo TJ, Break MK, Crouse KA, Tahirc MIM, Alid AM, Cowleye AR, Watkine DJ and Tarafderf MTH: Synthesis, characterization and biological activity of two Schiff base ligands and their nickel (II), copper(II), zinc(II) and cadmium(II) complexes derived from S-4-picolyldithiocarbazate and X-ray crystal structure of cadmium (II) complex derived from pyridine-2-carboxaldehyde. Inorganica Chim Acta 413: 68-76, 2014.

11. Fei BL, Xua WS, Tao HW, Li W, Zhang Y, Long JY, Liu QB, Xia B and Sun WY: Effects of copper ions on DNA binding and cytotoxic activity of a chiral salicylidene Schiff base. J Photochem Photobiol B 132: 36-44, 2014.

12. Nakao Y, Sakurai K and Nakahara A: Copper(II) chelates of Schiff bases derived from salicylaldehyde and various $\alpha$-amino acids. Bull Chem Soc Jpn 40: 1536-1538, 1967.

13. Krätsmár-Šmogrovič J, Pavelčík F, Soldánová J, Sivýa J, Seressová V and Žemlička M: The crystal and molecular structure and properties of diaqua (N-salicylidene-L-glutamato) copper (II) monohydrate. Z Naturforsch 46b: 1323-1327, 1991.

14. Langer V, Gyepesová D, Kohútová M and Valent A: Dimeric (isoquinoline) (N-salicylidene-D,L-glutamato)copper(II) ethanol solvate. Acta Cryst C65: 208-210, 2009.

15. Langer V, Gyepesová D, Scholtzová E, Mach P, Kohútová M, Valent A and Smrčok L': Crystal and electronic structure of aqua(N-salicylidene-methylester-L-glutamato) $\mathrm{Cu}(\mathrm{II})$ monohydrate. Z Kristallogr 219: 112-116, 2004.

16. Langer V, Mach P, Gyepesová, D, Andrezálová L and Kohútová M: X-ray and DFT studies of a mono- and binuclear copper (II) ionic compound containing a schiff base. Acta Cryst C68: M326-M328, 2012.

17. Langer V, Scholtzová E, Gyepesová D, Kohútová M and Valent A: (N-salicylidene-D, L-glutamato) (2-methylimidazole)copper(II). Acta Cryst E60: 129-132, 2004.

18. Buzdar AU, Marcus C, Smith TL and Blumenschen GR: Early and delayed clinical cardiotoxicity of doxorubicin. Cancer 55: 2761-2765, 1985.

19. Chung KK, Zhang Y, Lim KL, Tanaka Y, Huang H, Gao J, Ross CA, Dawson VL and Dawson TM: Parkin ubiquitinates the alpha-synuclein-interacting protein, synphilin-1: Implications for lewy-body formation in parkinson disease. Nat Med 7: 1144-1150, 2001

20. Lim KL, Chew KC, Tan JM, Wang C, Chung KK, Zhang Y, Tanaka Y, Smith W, Engelender S, Ross CA, et al: Parkin mediates nonclassical, proteasomal-independent ubiquitination of synphilin-1: Implications for lewy body formation. J Neurosci 25: 2002-2009, 2005.

21. Ho YT, Lu CC, Yang JS, Chiang JH, Li TC, Ip SW, Hsia TC, Liao CL, Lin JG, Wood WG and Chung JG: Berberine induced apoptosis via promoting the expression of Caspase 8, -9 and -3 , apoptosis-inducing factor and endonuclease G in SCC-4 human tongue squamous carcinoma cancer cells. Anti Res 29: 4063-4070, 2009. 
22. Xiao Y, Chen D, Zhang X, Cui Q, Fan Y, Bi C and Dou QP Molecular study on copper-mediated tumor proteasome inhibition and cell death. Int J Oncol 37: 81-87, 2010.

23. Rajalakshmi S, Kiran MS and Nair BU: DNA condensation by copper(II) complexes and their anti-proliferative effect on cancerous and normal fibroblast cells. Eur J Med Chem 80 : 393-406, 2014

24. Thati B, Noble A and Creaven SBS: Apoptotic cell death: A possible key event in mediating the in vitro anti-proliferative effect of a novel copper(II) complex, [Cu(4-Mecdoa)(phen)2] (phen=phenanthroline, 4-Mecdoa=4-methylcoumarin-6,7-dioxactetate), in human malignant cancer cells. Europ J Pharm 569: $16-28,2007$

25. Qiao X, Ma ZY, Shao J, Bao WG, Xu JY, Qiang ZY and Lou JS Biological evaluation of a cytotoxic 2-substituted benzimidazole copper (II) complex: DNA damage, antiproliferation and apoptotic induction activity in human cervical cancer cells Biometals 27: 155-172, 2014.

26. Barbosa IA, Machado NG, Skildum AJ, Scott PM and Oliveira PJ: Mitochondrial remodeling in cancer metabolism and survival: Potential for new therapies. Biochim Biophys Acta 1826: $238-254,2012$
27. Thomas S, Quinn BA, Das SK, Dash R, Emdad L, Dasgupta S, Wang XY, Dent P, Reed JC, Pellecchia M, et al: Targeting the Bcl-2 family for cancer therapy. Expert Opin Ther Targets 17: 61-75, 2013

28. Liu P, Brown S, Goktug T, Channathodiyil P, Kannappan V, Hugnot JP, Guichet PO, Bian X, Armesilla AL, Darling JL and Wang W: Cytotoxic effect of disulfiram/copper on human glioblastoma cell lines and ALDH-positive cancer-stem-like cells. Br J Cancer 107: 1488-1497, 2012.

29. Zuo J, Bi C, Fan Y, Buac D, Nardon C, Daniel KG and Dou QP Cellular and computational studies of proteasome inhibition and apoptosis induction in human cancer cells by amino acid schiff base-copper complexes. J Inorg Biochem 118: 83-93, 2013.

30. Zhang X, Bi C, Fan Y, Cui Q, Chen D, Xiao Y and Dou QP: Induction of tumor cell apoptosis by taurine schiff base copper complex is associated with the inhibition of proteasomal activity. Int J Mol Med 22: 677-682, 2008.

31. Xiao Y, Bi C, Fan Y, Cui C,Zhang X and Dou QP: L-glutamine schiff base copper complex as a proteasome inhibitor and an apoptosis inducer in human cancer cells. Int J Oncol 33: 1037-1079, 2008.

32. Khan KH, Codesido MB and Molife LR: Cancer therapeutics: Targeting the apoptotic pathway. Crit Rev Oncol Hematol 90: 200-219, 2014. 